\title{
Correction to: Protocol for a multicenter randomized controlled trial comparing a non-opioid prescription to the standard of care for pain control following arthroscopic knee and shoulder surgery
}

The NO PAin Investigators

Correction to: BMC Musculoskelet Disord 22, 471 (2021)

https://doi.org/10.1186/s12891-021-04354-x

Following the publication of the original article [1] the authors noticed that the authors "Aaron Gazendam, Seper Ekhtiari, Nolan S. Horner, Nicole Simunovic, Andrew Duong, Darren de Sa, Devin Peterson, Matthew Denkers, Vickas Khanna, Anthony Adili, Jaydeep Moro, Moin Khan, Olufemi R. Ayeni" are still not listed as the NO PAIN investigators in the published version. This was instructed during proofing stage but it was not implemented.

The original article [1] has been updated.

Published online: 10 July 2021

\section{Reference}

1. Gazendam A, Ekhtiari S, Horner NS, et al. Protocol for a multicenter

randomized controlled trial comparing a non-opioid prescription to the standard of care for pain control following arthroscopic knee and shoulder surgery. BMC Musculoskelet Disord. 2021;22:471. https://doi.org/10.1186/s12 891-021-04354-x.

The original article can be found online at https://doi.org/10.1186/s12891021-04354-x

\section{Correspondence:}

Department of Surgery, Division of Orthopaedic Surgery, McMaster

University, 1200 Main St West, 4E15, Hamilton ON L8N 3Z5, Canada

(c) The Author(s). 2021 Open Access This article is licensed under a Creative Commons Attribution 4.0 International License, which permits use, sharing, adaptation, distribution and reproduction in any medium or format, as long as you give appropriate credit to the original author(s) and the source, provide a link to the Creative Commons licence, and indicate if changes were made. The images or other third party material in this article are included in the article's Creative Commons licence, unless indicated otherwise in a credit line to the material. If material is not included in the article's Creative Commons licence and your intended use is not permitted by statutory regulation or exceeds the permitted use, you will need to obtain permission directly from the copyright holder. To view a copy of this licence, visit http://creativecommons.org/licenses/by/4.0/ The Creative Commons Public Domain Dedication waiver (http://creativecommons.org/publicdomain/zero/1.0/) applies to the data made available in this article, unless otherwise stated in a credit line to the data. 